\title{
Challenges of Curriculum Development in Office Technology and Management in Tertiary Institutions
}

\author{
Olukemi Josephine Omoniyi, Boluwaji Clement Elemure \\ Department of Office Technology and Management \\ The Federal Polytechnic, Ado-Ekiti, Nigeria
}

\begin{abstract}
This paper examines those challenges that affect the implementation of office technology and management programme in achieving its main objectives. Achieving programme objectives becomes a mirage if the implementation is faulty due to shortcomings and other inadequacies which have been the bane of most of the educational programmes in Nigeria. Office Technology and Management is a new academic programme that replaces the erstwhile secretarial studies in Nigeria which seeks to equip its recipients with the relevant knowledge and skills that are needed in this dynamic world of ours. The study covers Ekiti State in Nigeria. Relevant literatures were reviewed. The data collected were analyzed with mean ratings and standard deviation. It was found out that the curriculum of Office Technology and Management, if well implemented, will, to a great extent, address most of the issues and fears raised by stakeholders. Based on this, it was recommended among others that all stakeholders and management of institutions running Office Technology and Management programme in Nigeria should fund the programme adequately so as to ensure the availability of functional equipment and other resources that are needed in order to overcome the seemingly challenges that arise in the course of implementing the programme as stipulated in the curriculum.
\end{abstract}

\section{Introduction}

Office technology is the application of scientific knowledge, devices and systems to facilitate and enhance the information processes and delivery of same. It is also viewed as a concept that is associated with office automation, electronic technology and office globalization. Office Technology and Management is a new academic programme in Nigerian tertiary institutions designed to replace the secretarial studies programme. The need to prepare and make students of secretarial studies competent, skillful and employable in the world of work, which is being driven by technological content in the curriculum of erstwhile secretarial studies programme in the nation's tertiary institutions, gave birth to Office Technology and Management [1]. The OTM programme is designed to equip students with secretarial/office skills for employment in various fields of endeavours. Akwa citing NBTE asserted that in addition to the acquisition of vocational skills in Office Technology and Management, the students are equipped with effective work competencies and socio-psychological work skills which are very essential in every day interactions with others [2].

Oludele described curriculum implementation as a network of varying activities involved in translating curriculum design into classroom activities and changing people's attitudes to accept and participate in these activities [3]. Implementing the new, long awaited ICT-driven OTM curriculum expectedly threw up new challenges. The OTM curriculum was aimed at producing graduates who would be able to effectively manage the electronic driven office, and who would be equipped with secretarial and office skills for employment in various fields of endeavour. OTM curriculum developers envisage existence of solid internal evaluation for ensuring minimum standard and quality.

The new OTM programme incorporates the following six components in its design; Office Application, Office Technology, Business and Administrative Management, Numeric Component, General Studies and Students Industrial Work Experience Scheme (SIWES). OTM programme provides students with in-depth administrative office preparation to meet the demands and challenges in the business environment. Through the programme, students can obtain marketable skills applicable to various careers and industries as well as cognitive skills transferable to other employment situations and life experience. The design of OTM programme components appears to be responsive to a global initiative with an objective that portends new academic direction in favour of ICT [2]. The objectives, theoretical and practical contents of the new curriculum are geared towards integrating graduates of OTM department into the evolution of technology. 
Ike viewed that the whole idea about educational reforms in Nigeria, is the desire to produce an all round educated persons that will be economically useful, and conscientious members of our society [4]. Thus, in vocational office education, the aim is to provide for our system, the type of teaching/learning situations that focus not on artifacts, but on public knowledge, skills, competencies and reproducible ways. Omeje corroborated this when he maintained that business studies curriculum contents should be so reformed (redesigned) in such a way that a graduate of business education should be well equipped to be self-employed, thereby not only reducing unemployment but also creating employment [5]. Ike opined that the future of business education (Office Technology and Management inclusive) is going in the direction of integration of the following areas of emphasis in the existing curriculum and delivery [4].

o Competency based approach i.e. functional literacy

o Increased academic, critical and problem solving skills development

o Entrepreneurship based delivery

o Incorporation of establishment and utilization of production units within business institutions for practical work training and self-reliance and

o ICT based teaching/learning approaches.

Folahan further commented that the use of content and selectivity curriculum is a very potent one for modern curriculum developers, especially if goals of individuals i.e. learners and the nation as a whole are considered [6]. Thus curriculum, in essence, should enable learners to find meanings to their lives. Technological changes in the office have been tremendous that only innovation in the present curriculum content of Office Technology and Management can make its recipients fit into the automation office/world. The curriculum development in Office Technology and Management has no doubt its own implication among which are:

- Changing the individual orientation

- Creating new ways of thinking and tackling problems of research and experimentation

$\circ$ Training and developing new skills and competencies and
- Outlining new roles for teachers, students and administrators.

The success of Office Technology and Management programme would be measured and determined by the effectiveness, competence and job performance of the graduates of the programme. If the implementation of the curriculum, as viewed by [1] is deficient and faulty like some academic programmes in tertiary institutions in Nigeria that produce half-baked and poor graduates who cannot perform effectively and efficiently in the world of work, the graduates of the programme would also be deficient in knowledge and skill which would consequently make them ineffective and inefficient. The National Board for Technical Education whose statutory functions it is to formulate policies, including reviewing of curriculum for Polytechnic and Colleges of Technology in Nigeria has deemed it necessary to come up with the change of Secretarial Studies training to Office Technology and Management and in the view of [7 ], there is no doubt that when a programme is re-structured, the curriculum must be reviewed to meet the dynamics of the new programme, hence, some challenges are bound to emanate.

According to NBTE Office Technology and Management programme is designed to equip students with secretarial/office skills for employment in various fields of endeavour and students are equally equipped with effective work competencies and socio-psychological work skills, which are very essential in everyday interactions with others [8].

NBTE further viewed that graduates should fit properly into the office of any computerized organization and perform professionally, the function of a secretary which among others include - relating the functions of the office to the whole organization, attending meetings and providing information as may be required, making accurate records of proceedings, filling and retrieving information, taking appropriate action independently when faced with challenging secretarial office problems, showing personal qualities and attributes that are conducive and coexist with the work group [8].

The new curriculum and course specification as given by NBTE for Polytechnics in Nigeria is highlighted below [8].

Table 1. Course Outline for NDI First Semester

\begin{tabular}{|c|c|c|c|c|}
\hline Course Code & Course Title & $\mathrm{T}$ & $\mathrm{P}$ & $\mathrm{CH}$ \\
\hline GNS 101 & Use of English I & 2 & 2 & 4 \\
\hline GNS 111 & Citizenship Education & 1 & 1 & 2 \\
\hline BAM 111 & Introduction to Business I & 2 & 1 & 3 \\
\hline OTM 111 & Shorthand I & 2 & 2 & 4 \\
\hline OTM 113 & Information and Communication Technology I & 1 & 7 & 8 \\
\hline
\end{tabular}




\begin{tabular}{|l|l|c|c|c|}
\hline OTM 114 & Office Practice I & 1 & 3 & 4 \\
\hline OTM 112 & Keyboarding I & 2 & 2 & 4 \\
\hline & TOTAL & 11 & 18 & 29 \\
\hline
\end{tabular}

Note:

$\mathrm{T}$ - Theory

P - Practical

$\mathrm{CH}$ - Credit Hour

Table 2. Course Outline for NDI Second Semester

\begin{tabular}{|l|l|c|c|c|}
\hline Course Code & Course Title & T & P & CH \\
\hline GNS 102 & Communication in English & 2 & 2 & 4 \\
\hline OTM 123 & Information Communication Technology II & 1 & 7 & 8 \\
\hline GNS 121 & Citizenship Education II & 1 & 1 & 2 \\
\hline BAM 126 & Introduction to Entrepreneurship & 1 & 2 & 3 \\
\hline BAM 113 & Principles of Law & 1 & 1 & 2 \\
\hline OTM 125 & Career Development & 2 & 2 & 4 \\
\hline OTM 121 & Shorthand II & 2 & 2 & 4 \\
\hline OTM 124 & Modern Office Technology & 1 & 3 & 4 \\
\hline OTM 122 & Keyboarding II & 2 & 2 & 4 \\
\hline & TOTAL & 11 & 20 & 31 \\
\hline
\end{tabular}

Table 3. Course Outline for ND II First Semester

\begin{tabular}{|l|l|c|c|c|}
\hline Course Code & Course Title & T & P & CH \\
\hline GNS 201 & Use of English II & 2 & 2 & 4 \\
\hline GNS 228 & Research Techniques & 2 & 2 & 2 \\
\hline OTM 211 & Shorthand III & 1 & 3 & 4 \\
\hline OTM 214 & Office Practice II & 1 & 3 & 4 \\
\hline OTM 213 & Desktop Publishing & 1 & 5 & 6 \\
\hline ACC 111 & Principles of Accounting & 1 & 3 & 4 \\
\hline OTM 212 & Keyboarding III & 2 & 2 & 4 \\
\hline & TOTAL & 10 & 20 & 30 \\
\hline
\end{tabular}

Table 4. Course Outline for ND II Second Semester

\begin{tabular}{|l|l|c|c|c|}
\hline Course Code & Course Title & T & P & CH \\
\hline GNS 202 & Communication in English II & 2 & 2 & 4 \\
\hline OTM 222 & Records Management & 1 & 1 & 2 \\
\hline BAM 114 & Principles of Economics I & 2 & 1 & 3 \\
\hline OTM 223 & Web Page Design & 1 & 7 & 8 \\
\hline OTM 221 & Peoples Communication Skills & 1 & 3 & 4 \\
\hline OTM 226 & SIWES & - & $(2)$ & $(2)$ \\
\hline OTM 225 & Project & - & 4 & 4 \\
\hline & TOTAL & 7 & 18 & 25 \\
\hline
\end{tabular}

In the curriculum, Career Development, Web Page Design and People Communication Skills were embedded. These show further improvement in the curriculum and if the course contents are rigidly implemented, graduates would no doubt have additional skills and competencies needed in the world of technology.

Table 5. Course Outline for HND I First Semester

\begin{tabular}{|l|l|c|c|c|}
\hline Course Code & Course Title & T & P & CH \\
\hline OTM 311 & Shorthand IV & 1 & 3 & 4 \\
\hline
\end{tabular}




\begin{tabular}{|l|l|c|c|c|}
\hline OTM 313 & ICT Office Application I & 2 & 6 & 8 \\
\hline OTM 314 & Office Administration and Management I & 2 & 2 & 4 \\
\hline OTM 312 & Business Communication I & 2 & 2 & 4 \\
\hline GNS 411 & Social Psychology & 2 & 2 & 4 \\
\hline BAM 214 & Business Law & 2 & 2 & 4 \\
\hline & TOTAL & 11 & 17 & 28 \\
\hline
\end{tabular}

Table 6. Course Outline for HND I Second Semester

\begin{tabular}{|l|l|c|c|c|}
\hline Course Code & Course Title & T & P & CH \\
\hline OTM 321 & Business Communication II & 2 & 2 & 4 \\
\hline OTM 322 & ICT Office Application II & 2 & 6 & 8 \\
\hline OTM 323 & Office Administration \& Management II & 2 & 2 & 4 \\
\hline OTM 324 & Research Methods & 1 & 3 & 4 \\
\hline OTM 325 & Professional Career Development & 2 & 2 & 4 \\
\hline BAM 324 & Human Capital Management & 2 & 2 & 4 \\
\hline BAM 427 & Nigerian Labour Law & 2 & 2 & 4 \\
\hline & TOTAL & 13 & 19 & 32 \\
\hline
\end{tabular}

Table 7. Course Outline for HND II First Semester

\begin{tabular}{|l|l|c|c|c|}
\hline Course Code & Course Title & T & P & CH \\
\hline OTM 411 & Advanced Transcription & 1 & 3 & 4 \\
\hline GNS 402 & Literacy Appreciation and Oral Composition & 1 & 1 & 2 \\
\hline OTM 413 & Database Management Systems & 1 & 3 & 4 \\
\hline OTM 414 & Oral Communication Skills & 1 & 3 & 4 \\
\hline OTM 415 & Advanced Desktop Publishing & 2 & 6 & 6 \\
\hline BAM 224 & Elements of Human Capital Management & 2 & 1 & 3 \\
\hline & TOTAL & 8 & 17 & 23 \\
\hline
\end{tabular}

Table 8. Course Outline for HND II Second Semester

\begin{tabular}{|l|l|c|c|c|}
\hline Course Code & Course Title & T & P & CH \\
\hline OTM 432 & Management Information Systems & 11 & 3 & 4 \\
\hline OTM 424 & Professional Ethics and Social Responsibility & 2 & 2 & 4 \\
\hline BAM 426 & Entrepreneurship Development & 2 & 2 & 4 \\
\hline OTM 425 & Advanced Web Page Design & 2 & 6 & 8 \\
\hline OTM 422 & Project & - & 4 & 4 \\
\hline & TOTAL & 7 & 17 & 24 \\
\hline
\end{tabular}

The features of the curriculum at this level were the inculcation of more subjects that make the recipients to be more useful, relevant and dynamic in a changing world like ours. Noticeable are other relevant courses that are still needful to be incorporated into the curriculum for better delivery. The goals of higher education according to Oludele include developing intellectual capabilities of individuals to understand and appreciate their environments and to acquire physical and intellectual skills which will enable them to be self-reliant and useful members of the society [3]. According to Oludele, Office Technology and Management (OTM) curriculum was aimed at producing graduates who would have acquired intellectual and professional skills to be able to effectively manage the electronicdriven office [3]. OTM graduates should therefore fit properly into the office of any computerized organization and perform professionally the functions of a secretary. This paper therefore examines those challenges that may be encountered in the process of implementing the programme of office technology and management as stipulated in the curriculum in Nigeria.

\section{Statement of the Problem}

The new curriculum of Office Technology and Management has no doubt come with some 
challenges that must be met by both the teachers and the students in order to achieve the general objectives of the programme. The resources namely, human, material and financial which are the basic requirements for the attainment of the objectives of the new programme are not adequate. The challenges include lack of funds, insufficient number of ICT gadgets and lack of trained subject teachers for proper integration of computers into learning areas.

\section{Purpose of the Study}

The purpose of this study is to specifically

- Identify the current challenges on the implementation of office technology and management curriculum in Nigeria

- Sort out the strategies for implementing the curriculum of office technology and management in Nigeria.

- Identify other areas where office technology and management could further be enriched.

\section{Research Questions}

The following research questions were raised for the study

- Are there challenges on the implementation of Office Technology and Management curriculum in Nigeria?

- Are there strategies that can be adopted for the implementation of Office Technology and Management curriculum in Nigeria?

- Are there areas where Office Technology and Management curriculum could further be enriched?

\section{Methodology}

The survey design was adopted for the study. The population of the study was made up of all academic staff, practicing secretarial/office staff and final year of Business/Office Technology and Management students in various tertiary institutions in Ekiti State, Nigeria. Using random sampling technique, a sample of 80 respondents was used for the study. Questionnaire was the main instrument used for the study and was validated by experts for both face and content structures. The items in the questionnaire were structured in such a way that respondents expressed their candid opinion in a five point Likert rating scale of strongly agree, agree, disagree, strongly disagree and undecided. The data collected were analyzed using mean ratings and standard deviation to answer each of the three research questions. The mean of the responses to each item was computed and interpreted based on the statistical real limits of the numbers as follows: Strongly agreed (5points), Agree (4 points), Disagree (3 points), Strongly disagree ( 2 points) and Undecided (1 point). In taking decision for the research questions, a mean score of 3.00 and above was considered as agreed while a mean score below it was considered as disagreed.

\section{Data Analysis}

Research Question 1: Are there challenges on the implementation of office technology and management curriculum in Nigeria?

Table 9. Mean Rating and Standard Deviation of Respondents on the Challenges of OTM Curriculum Implementation

\begin{tabular}{|c|c|c|c|c|c|c|c|c|c|}
\hline $\mathrm{S} / \mathrm{No}$ & Item Statement & SA & $\mathrm{A}$ & $\mathrm{D}$ & SD & $\mathrm{U}$ & $\mathrm{X}$ & SD & Decision \\
\hline 1. & $\begin{array}{l}\text { Arbitrary implementation of Office Technology } \\
\text { and Management programme. }\end{array}$ & 24 & 29 & 10 & 7 & 10 & 3.63 & 1.33 & Accepted \\
\hline 2. & Teacher overwork & 13 & 21 & 29 & 14 & 3 & 3.34 & 1.05 & Accepted \\
\hline 3. & $\begin{array}{l}\text { Inadequate supply of ICT equipment and } \\
\text { facilities }\end{array}$ & 28 & 25 & 20 & 6 & 1 & 3.91 & 1.00 & Accepted \\
\hline 4. & $\begin{array}{l}\text { Poorly equipped libraries, laboratories and lecture } \\
\text { rooms }\end{array}$ & 27 & 26 & 19 & 7 & 1 & 3.89 & 1.01 & Accepted \\
\hline 5. & Inadequate classroom accommodation & 34 & 26 & 12 & 7 & 1 & 4.06 & 1.02 & Accepted \\
\hline 6. & Poor societal attitude & 21 & 26 & 22 & 6 & 5 & 3.65 & 1.13 & Accepted \\
\hline 7. & $\begin{array}{l}\text { Dearth of qualified teachers/personnel to integrate } \\
\text { computer into learning areas }\end{array}$ & 19 & 28 & 15 & 9 & 9 & 3.49 & 1.27 & Accepted \\
\hline 8. & Unstable teaching staff & 15 & 20 & 31 & 14 & - & 3.45 & 0.99 & Accepted \\
\hline 9. & The poor state of the economy & 22 & 34 & 14 & 9 & 1 & 3.84 & 0.99 & Accepted \\
\hline 10. & Corruption & 20 & 27 & 21 & 11 & 1 & 3.68 & 1.03 & Accepted \\
\hline 11. & Scarcity and prohibitive cost of books & 14 & 25 & 27 & 12 & 2 & 3.46 & 1.02 & Accepted \\
\hline
\end{tabular}




\begin{tabular}{|l|l|l|l|l|l|l|l|l|l|}
\hline 12. & Unfavourable government policy & 31 & 31 & 11 & 6 & 1 & 4.06 & 0.97 & Accepted \\
\hline 13. & Incessant strike actions & 52 & 14 & 11 & 2 & 1 & 4.43 & 0.91 & Accepted \\
\hline 14. & Epileptic power supply & 35 & 23 & 15 & 5 & 2 & 4.05 & 1.05 & Accepted \\
\hline
\end{tabular}

Field Survey, 2014

From the analysis of the data and the responses by the respondents, a large number of the respondents agreed that there are challenges on the implementation of OTM curriculum. This is so because all the items have mean rating of not less than 3.00 .
Research Question 2: Are there strategies that can be adopted for the implementation of office technology and management curriculum in Nigeria?

Table 10. Mean Rating and Standard Deviation of Respondents on Strategies for the Implementation of OTM Curriculum

\begin{tabular}{|l|l|l|l|l|l|l|l|l|l|}
\hline S/No & Item Statement & SA & A & D & SD & U & X & SD & Decision \\
\hline 1. & $\begin{array}{l}\text { Employment of qualified and competent } \\
\text { teachers }\end{array}$ & 31 & 33 & 10 & 5 & 1 & 4.10 & 0.93 & Accepted \\
\hline 2. & $\begin{array}{l}\text { Training and retraining of teachers/personnel } \\
\text { through regular workshop/conferences }\end{array}$ & 37 & 30 & 7 & 4 & 2 & 4.20 & 0.97 & Accepted \\
\hline 3. & Consistency in government policy & 32 & 27 & 11 & 8 & 2 & 3.99 & 1.08 & Accepted \\
\hline 4. & Improved funding & 24 & 26 & 16 & 6 & 8 & 3.65 & 1.26 & Accepted \\
\hline 5. & $\begin{array}{l}\text { Properly equipped automated instructional } \\
\text { equipment }\end{array}$ & 35 & 26 & 8 & 7 & 4 & 4.01 & 1.16 & Accepted \\
\hline 6. & $\begin{array}{l}\text { Development of new methods of instruction } \\
\text { by teachers/lecturers }\end{array}$ & 35 & 30 & 9 & 2 & 4 & 4.12 & 1.04 & Accepted \\
\hline 7. & Dedication on the part of teachers/lecturers & 27 & 41 & 4 & 4 & 4 & 4.04 & 1.01 & Accepted \\
\hline 8. & Organized teacher development programme & 32 & 32 & 4 & 5 & 7 & 3.96 & 1.22 & Accepted \\
\hline 9. & $\begin{array}{l}\text { Ownership of personal computer by every } \\
\text { business educator }\end{array}$ & 26 & 31 & 13 & 5 & 5 & 3.85 & 1.13 & Accepted \\
\hline 10. & Effective evaluation system & 32 & 28 & 12 & 2 & 6 & 3.98 & 1.15 & Accepted \\
\hline 11. & Institution-industry collaboration & 20 & 36 & 11 & 6 & 7 & 3.70 & 1.16 & Accepted \\
\hline 12. & $\begin{array}{l}\text { Provision of adequate training facilities and } \\
\text { equipment }\end{array}$ & 37 & 25 & 9 & 6 & 3 & 4.09 & 1.07 & Accepted \\
\hline
\end{tabular}

Field Survey, 2014

The data presented in table 2 above shows that all the item raised could serve as good strategies for the implementation of OTM curriculum in Nigeria. This can be seen from the response of the respondents with a mean of not less than 3.00 in all the items.
Research Question 3: Are there areas where Office Technology and Management curriculum could further be enriched?

Table 11. Mean Rating and Standard Deviation of Respondents on Further Improvement on Office Technology and Management Curriculum

\begin{tabular}{|l|l|l|l|l|l|l|l|l|l|}
\hline S/No & Item Statement & SA & A & D & SD & U & X & SD & Decision \\
\hline 1. & Application package for graphics & 34 & 36 & 6 & 2 & 2 & 4.23 & 0.88 & Accepted \\
\hline 2. & Word Processing & 38 & 34 & 3 & 3 & 2 & 4.29 & 0.90 & Accepted \\
\hline 3. & Corporate Administration & 37 & 32 & 8 & 1 & 2 & 4.26 & 0.88 & Accepted \\
\hline 4. & Corporate Governance & 28 & 36 & 10 & 2 & 4 & 4.03 & 1.01 & Accepted \\
\hline 5. & More courses on Entrepreneurial Education & & & & & & & & \\
& & 30 & 31 & 12 & 6 & 1 & 4.04 & 0.97 & Accepted \\
\hline 6. & Computer programming & 36 & 35 & 6 & 2 & 1 & 4.29 & 0.81 & Accepted \\
\hline
\end{tabular}




\begin{tabular}{|l|l|l|l|l|l|l|l|l|l|}
\hline 7. & Basic Networking & 32 & 33 & 9 & 4 & 2 & 4.11 & 0.96 & Accepted \\
\hline 8. & ICT Maintenance and Repairs & 35 & 31 & 4 & 5 & 5 & 4.08 & 1.14 & Accepted \\
\hline 9. & Software/Application package installation & & & & & & & & \\
& & 41 & 26 & 6 & 4 & 3 & 4.23 & 1.04 & Accepted \\
\hline 10. & Computer Safety Practice (Ergonomics) & 32 & 32 & 6 & 7 & 3 & 4.04 & 1.08 & Accepted \\
\hline
\end{tabular}

Field Survey, 2014

The data presented in table 3 above shows that a large number of the respondents agreed that all the above listed courses should be included in OTM curriculum in order to further enrich the programme. This could be adjudged from the fact that all the items show a mean of not less than 3.00.

\section{Discussion of Results}

This study examined the challenges of OTM curriculum implementation in Nigeria. From the findings, it is clear that the curriculum has come with some challenges that would be faced by both teachers and students in order to achieve its general aims and objectives. This agrees with the view of Adeola which pointed out that in majority of Nigerian institutions, the classroom accommodation is grossly inadequate while many of these institutions have poorly equipped libraries, laboratories and lecture rooms [9]. According to them, implementing curriculum in Nigeria is faced with the challenge of provision of sufficient fund. Curriculum innovation lacks adequate attention and sponsorship by the government due to lack of fund. This was in agreement with the view of Ike, who posited that the new curriculum of Office Technology and Management has made it more capital intensive and demanding and computers which are basic to all teaching and learning activities involving teachers and students are just not there in the laboratories and classrooms, and where they exist, they are few in number [4].

Eze further observed that certain facilities are specially designed to enhance the teaching of skills in OTM without which such skills cannot be acquired but it is very disturbing that our institutions is very retarded in terms of technological equipment [10]. They further observed that there is absence of adequate functional laboratories, model office and equipment in most of our institutions of higher learning and there is need to continually inform the government of the need to enrich students' experiences with modern teaching audio-visual devices.

In the same vein, Oludele posited that almost all training facilities for acquiring the professional skills specified in the curriculum are electricity-driven and the erratic power supply situation of the nation poses a major challenge to effective implementation of ICT-based OTM curriculum [3]. They further stressed that the cost of equipment is enormous in a country like Nigeria with a crippled economy and terribly devalued currency. According to them, the huge financial requirements for the procurement and installation of hardware and software necessary for implementation of the ICT-based OTM curriculum pose a great challenge coupled with the fundamental challenge of funding which is regarded as the mother of many other challenges confronting the implementation of the curriculum. Inadequate funding accounts for inadequate supply of training facilities and also makes maintaining the available ones a difficult task.

The result of the findings further shows that various strategies can be adopted in ensuring the successful implementation of the OTM curriculum in Nigeria. In the view of Eze, OTM programmes are very expensive and need to be given special funding attention and government should also improve substantially the monitoring of its implementation strategies not only to ensure accountability of funds but also for effective teaching and learning [10]. They further submitted that the anticipated progress in OTM cannot be contemplated in the absence of very vigorous consistent policies to improve and update vocational education and therefore institutions offering OTM programmes should be properly equipped with new and more automated instructional equipment. Consequently, Adeola stressed that the teachers employed to teach OTM should be competent and qualified in terms of professional qualification, practical skills and knowledge and should be able to know both the content and methodology of the subject to foster effective teaching and learning [9].

The findings of the study also pointed out to the fact that the content of the OTM curriculum still need to be enriched with other beneficial courses. Olawole remarked that vocational education philosophy was built on the production of graduates who will be equipped with all necessary skills and knowledge that will not only enable them fit into already existing job opportunity in the society but will also empower them with skills that will enable them establish their own business and if possible create job opportunities 
for others [11]. He further submitted that a careful study of the present OTM curriculum from the National Board for Technical Education (NBTE) only made provision for the teaching of one desktop application package which is titled Advanced Desktop Publishing. The curriculum also makes provision for the teaching of Advanced Web page design which limits the skill and knowledge of OTM students and graduates to the designing of web page which is an integral part of a website. In view of this, Olawole posited that there is need to enrich the curriculum by adding the teaching of one application package for graphics in the curriculum and also the need for the inclusion of website designing in the OTM curriculum so that the job/entrepreneurial prospects of OTM graduates can be brightened or enhanced [11].

\section{Conclusion}

Office Technology and Management is indeed a laudable educational programme. It is an innovative response to the new demands of the world of work particularly the business world. Based on the findings of the study, there are various challenges to contend with in the course of implementing the curriculum of OTM which ranges from inadequacy in the supply of ICT equipment and facilities to unstable teaching staff and inadequate funding. However, these challenges could be overcome if the various strategies which include the provision of adequate training facilities/equipment and consistency in government policy are adopted. The curriculum of OTM could further be enriched with the inclusion of other relevant courses that will not only make the graduate to be marketable but also self-reliant.

\section{Recommendations}

Based on the findings of this study and the conclusion drawn, the researcher hereby recommends that

1. Government and all other stakeholders in education sector should make provision for adequate facilities and training equipment for effective service delivery and implementation of OTM curriculum.

2. Government at the national, state and local government level together with all other relevant stakeholders in the educational sector should priotise adequate funding of education in the country.

3. Adequate and regular plan should be made by government for the training and retraining of teachers in order to enhance their capability in skills and competence needed in the delivery of the curriculum of OTM.

4. A review of the curriculum of OTM should be made by the National Board for Technical Education (NBTE) and National University Commission (NUC) in case of Universities offering the course by including more courses that have entrepreneurial opportunities.

5. The various resources that are essential requirements in the teaching and learning process should be provided by institutions offering the course to enable students have more practical learning experience.

\section{References}

[1] Olawole S.A. and Abuya A.O. (2011). Measures for Effective Implementation of Office Technology and Management Programme in Tertiary Educational Institutions in Nigeria, Journal for the advancement of Office Technology and Management 5 (1).

[2] Akwa J.C. and Pwol D.Y. (2009). Entrepreneurship Opportunities in Office Technology and Management, Secretarial Forum (4).

[3] Oludele L.Y. and Dosunmu J.O. (2013). Effective Curriculum Implementation: Pathway to Quality Assurance in Office Technology and Management, Association of Business Educators of Nigeria, Book of Readings, 3 (1).

[4] Ike M. (2008). A Critique of the New Curriculum in Office Technology and Management,

Business Education Journal VI (2).

[5] Omeje T.S. (2008). Imperatives for Reforming the Secretarial Studies Curriculum in Nigeria,

Business Education Journal VI (2).

[6] Folahan S.A.and Monofi (2003).Business Education and Development in Office Automation: The need for Curriculum Innovation, Association of Business Education of Nigeria (Ondo and Ekiti State Journal) 1 (1).

[7] Ogiagah Z.M. (2009). Current Issues in Office Technology and Management Curriculum, Secretarial Forum (4).

[8] NBTE (2004). Office Technology and Management Curriculum \& Course Specifications.

[9] Adeola K.L. and Bolarinwa K.O. (2010). Strategies for Promoting Entrepreneurship Education in Secondary School Curriculum, Association of Business Educators of Nigeria, Book of Readings 1(10). 
[10] Eze M.E. and Ugwuanyi M.O. (2008). Projecting of Business Education in Nigeria into the end of first Quarter of 21st Century, Business Education Journal VI(2).

[11] Olawole S.A. (2013). Enriching the Job/Entrepreneurial Opportunities in Office Technology and Management Programme in Nigerian Polytechnics, Journal of Business Educators of Nigeria, Ondo and Ekiti States Chapter II(2).

\section{QUESTIONNAIRE ON CHALLENGES OF CURRICULUM DEVELOPMENT IN OFFICE TECHNOLOGY AND MANAGEMENT IN TERTIARY INSTITUTIONS}

\section{Dear Sir/Ma}

This questionnaire is meant to elicit information on 'Challenges of Curriculum Development in Office Technology and Management in Tertiary Institutions'. This study is strictly for research purpose and your genuine response to each of the items will be greatly appreciated.

Thank you.

Elemure, C. B.

Name of Institution:

Department:

Sex:

Male

Female

Instruction: In responding to the questionnaire items, please, tick any of the options provided that correctly matches your opinion.

\section{The Challenges of OTM Curriculum Implementation}

\begin{tabular}{|l|l|l|l|l|l|l|}
\hline S/No & Item Statement & SA & A & D & SD & U \\
\hline 1. & $\begin{array}{l}\text { Arbitrary implementation of Office } \\
\text { Technology and Management programme. }\end{array}$ & & & & \\
\hline 2. & Teacher overwork & & & & & \\
\hline 3. & $\begin{array}{l}\text { Inadequate supply of ICT equipment and } \\
\text { facilities }\end{array}$ & & & & \\
\hline 4. & $\begin{array}{l}\text { Poorly equipped libraries, laboratories and } \\
\text { lecture rooms }\end{array}$ & & & & \\
\hline 5. & Inadequate classroom accommodation & & & & & \\
\hline 6. & Poor societal attitude & & & & & \\
\hline 7. & $\begin{array}{l}\text { Dearth of qualified teachers/personnel to } \\
\text { integrate computer into learning areas }\end{array}$ & & & & & \\
\hline 8. & Unstable teaching staff & & & & & \\
\hline 9. & The poor state of the economy & & & & & \\
\hline 10. & Corruption & & & & \\
\hline 11. & Scarcity and prohibitive cost of books & & & & & \\
\hline 12. & Inadequate funding & & & & & \\
\hline
\end{tabular}




\begin{tabular}{|l|l|l|l|l|l|l|}
\hline 13. & Unfavourable government policy & & & & & \\
\hline 14. & Incessant strike actions & & & & & \\
\hline 15. & Epileptic power supply & & & & & \\
\hline
\end{tabular}

Strategies for the implementation of OTM curriculum

\begin{tabular}{|c|c|c|c|c|c|c|}
\hline S/No & Item Statement & SA & A & $\mathrm{D}$ & SD & $\mathrm{U}$ \\
\hline 1. & $\begin{array}{l}\text { Employment of qualified and competent } \\
\text { teachers }\end{array}$ & & & & & \\
\hline 2. & $\begin{array}{l}\text { Training and retraining } \\
\text { teachers/personnel of } \\
\text { workshop/conferences }\end{array}$ & & & & & \\
\hline 3. & Consistency in government policy & & & & & \\
\hline 4. & Improved funding & & & & & \\
\hline 5. & $\begin{array}{l}\text { Properly equipped automated instructional } \\
\text { equipment }\end{array}$ & & & & & \\
\hline 6. & $\begin{array}{l}\text { Development of new methods of } \\
\text { instruction by teachers/lecturers }\end{array}$ & & & & & \\
\hline 7. & $\begin{array}{l}\text { Dedication on the part of } \\
\text { teachers/lecturers }\end{array}$ & & & & & \\
\hline 8. & $\begin{array}{lll}\text { Organized } & \text { teacher } & \text { development } \\
\text { programme }\end{array}$ & & & & & \\
\hline 9. & $\begin{array}{l}\text { Ownership of personal computer by every } \\
\text { business educator }\end{array}$ & & & & & \\
\hline 10. & $\begin{array}{l}\text { Provision of adequate training facilities } \\
\text { and equipment }\end{array}$ & & & & & \\
\hline 11. & Institution-industry collaboration & & & & & \\
\hline 12. & $\begin{array}{l}\text { Provision of adequate training facilities } \\
\text { and equipment }\end{array}$ & & & & & \\
\hline
\end{tabular}

\section{Improving office technology and management curriculum}

\begin{tabular}{|l|l|l|l|l|l|l|}
\hline S/No & Item Statement & SA & A & D & SD & U \\
\hline & $\begin{array}{l}\text { The following should be incorporated to } \\
\text { improve OTM curriculum }\end{array}$ & & & & \\
\hline 1. & Application package for graphics & & & & & \\
\hline 2. & Word Processing & & & & & \\
\hline 3. & Corporate Administration & & & & & \\
\hline 4. & Corporate Governance & & & & \\
\hline 5. & More courses on Entrepreneurial Education & & & & & \\
\hline 6. & Computer programming & & & & & \\
\hline 7. & Basic Networking & & & & & \\
\hline 8. & ICT Maintenance and Repairs & & & & \\
\hline 9. & Software/Application package installation & & & & & \\
\hline 10. & Computer Safety Practice (Ergonomics) & & & & & \\
\hline
\end{tabular}

